\title{
Chapter 5 Neglected Values of Major Water Engineering Projects: Ecosystem Services, Social Impacts, and Economic Valuation
}

\author{
Bernd Hansjürgens, Nils Droste, and Klement Tockner
}

\begin{abstract}
Major water infrastructure projects like dams can provide substantial benefits such as food and drinking water security, hydropower generation, and flood control. But these benefits may come at a (too) high cost of large scale ecological alterations or adverse social impacts such as involuntary resettlements. If these costs are neglected, an investment decision will hardly be efficient. In this chapter, we will stress the necessity to make these "neglected values" visible and demonstrate how this can be achieved through economic valuation.
\end{abstract}

Keywords Major water engineering projects $\bullet$ Dams $\bullet$ Ecosystem services $\bullet$ Social impacts • Economic valuation $\bullet$ Ecological trade-offs $\bullet$ Distributional impacts • World Commission on Dams • Benefits • Costs

\footnotetext{
B. Hansjürgens ( $\square)$

Department of Economics, Helmholtz Centre for Environmental

Research - UFZ, Permoserstraße 13, 04318 Leipzig, Germany

e-mail: bernd.hansjuergens@ufz.de

N. Droste

Helmholtz Centre for Environmental Research - UFZ,

Permoserstraße 13, 04318 Leipzig, Germany

K. Tockner

Leibniz-Institute of Freshwater Ecology and Inland Fisheries (IGB),

Müggelseedamm 310, 12587 Berlin, Germany

Department of Biology, Chemistry and Pharmacy, Freie Universität Berlin,

Altensteinstraße 6, 14195 Berlin, Germany

e-mail: tockner@ibg-berlin.de
} 


\subsection{Controversial Discussions About Benefits and Costs of Major Water Engineering Projects}

The main challenge for water and energy resource developers in the 21 st century will be to improve options assessment and the performance of existing assets. This will require open, accountable and comprehensive planning and decision-making procedures for assessing and selecting from the available options (World Commission on Dams 2000, p. 166).

Major water engineering projects (MWEPs) such as dams are subject to a controversial debate about their role for development. Especially where water is scarce and poverty widespread, water infrastructure can improve the livelihood of people. Large dams can facilitate access to water in water-scarce regions by improved ground water levels and increased flows in downstream areas during water scarce periods; thereby increasing food security (Shah and Kumar 2008). In addition to irrigation, water supply and flood control, electricity generation by hydropower has been a major driver for many large-scale water infrastructure projects (Biswas and Tortajada 2001). These large-scale projects are often co-financed by international organisations such as the World Bank and increasingly by private investors (Moore et al. 2010; Zarfl et al. 2015).

To assess the performance of such investments, the World Bank jointly with the International Union for Conservation of Nature (IUCN) initiated a multi-stakeholder dialogue in 1997. The final report of the World Commission on Dams (WCD) concluded that "dams have made an important and significant contribution to human development, and the benefits derived from them have been considerable. In too many cases an unacceptable and often unnecessary price has been paid to secure those benefits, especially in social and environmental terms, by people displaced, by communities downstream, by taxpayers and by the natural environment" (World Commission on Dams 2000, p. xxviii). While the core principles and strategic priorities of the report were broadly accepted, the guidelines for practical implementation resulted in dissent (Moore et al. 2010). Especially professional associations such as the International Commission on Large Dams (ICOLD) criticised the report for omitting benefits of large-scale dam constructions and calling for procedures that would deter large dam investments (Varma 2001).

The ongoing debate on large-scale water infrastructure remains controversial. Shah and Kumar (2008) analyse large dams in 145 countries and find that the main arguments for large dams are food and drinking water security, hydropower generation, and flood control. The criticism against large dams generally focuses on environmental, financial, economic, and human rights issues (ibid.). A very recent study finds (1) on average large cost and schedule overruns in the construction of large dams and (2) that risks are not sufficiently taken into account; therefore, smaller scale projects with less associated risks are strongly recommended (Ansar et al. 2014).

Whether a dam (or any similar large water infrastructure project) yields societal welfare gains or losses mainly depends on its specific characteristics. But as a general principle any assessment aiming towards a comprehensive analysis has to include all related costs and benefits of different infrastructure options. 
Along this basic principle, we will give an overview of large dams that have emerged worldwide during recent years. We will then focus on the costs and benefits of MWEPs with special attention to the often neglected values of ecosystem services and distributional effects for society.

\subsection{The Emergence of Major Water Engineering Projects Worldwide: Large Dams on the Advance}

Hydropower production is a very well-established technique of the electricity system. Worldwide, out of 37,600 dams higher than $15 \mathrm{~m}$ more than 8,600 dams for hydropower generation are in operation, contributing about $20 \%$ to the global electricity production. A period of intense dam building has been observed from the 1930s to the 1970s in North America, Japan and Western Europe. Major hydropower dam building in industrialised countries has now slowed, partly because the best sites have already been exploited within these countries, but also due to a greater understanding of the often unexpected social, economic, and environmental costs (Poff and Hart 2002; Lehner et al. 2011; ICOLD 2014).

Large dams mean high risks. Indeed, on average, the construction of large dams took much longer than planned and the expenses were twice as high as calculated. Furthermore, social and ecological costs were often not included because they are difficult to be calculated. Therefore, large dams, as well as other large infrastructure projects, are considered economically ineffective and should not be favoured (Ansar et al. 2014).

Despite the expected risks, we actually face an unprecedented boom in hydropower dam construction worldwide, primarily in developing countries and emerging economies (Zarfl et al. 2015, Fig. 5.1). While the expected construction of more than 3700 major dams may almost double the global electricity production from hydropower, it also may reduce the number of the last remaining large freeflowing rivers by about $20 \%$, in particular in South America. Many of the future dams are planned in areas with an exceptional high freshwater biodiversity. The Mekong, Amazon, and Congo basins are biodiversity hot spots that together contain about $1 / 5$ of the global freshwater fish diversity. In particular, these basins will be heavily impacted by future hydropower development. Similarly, the Balkan area and Turkey face a major boom in dam construction; both regions are major centres of freshwater biodiversity.

Dam construction is becoming more and more a global business. A recent analysis on involved investors demonstrates that an increasing number of dam projects are financed by internationally operating companies (Zarfl et al. 2015). The construction costs of the 3700 dams planned or under construction may amount up to USD 2 trillion within the coming 10-20 years, excluding running and maintenance costs. Considering the fact that the costs and the construction timelines are systematically underestimated, we may expect costs that are at least twice as high. This is in line with Ansar et al. (2014) who find a mean cost overrun of $96 \%$ in the construction of dams. At the same time, there are doubts that the projected increase in hydropower production will close the so-called electricity gap, i.e. providing access 


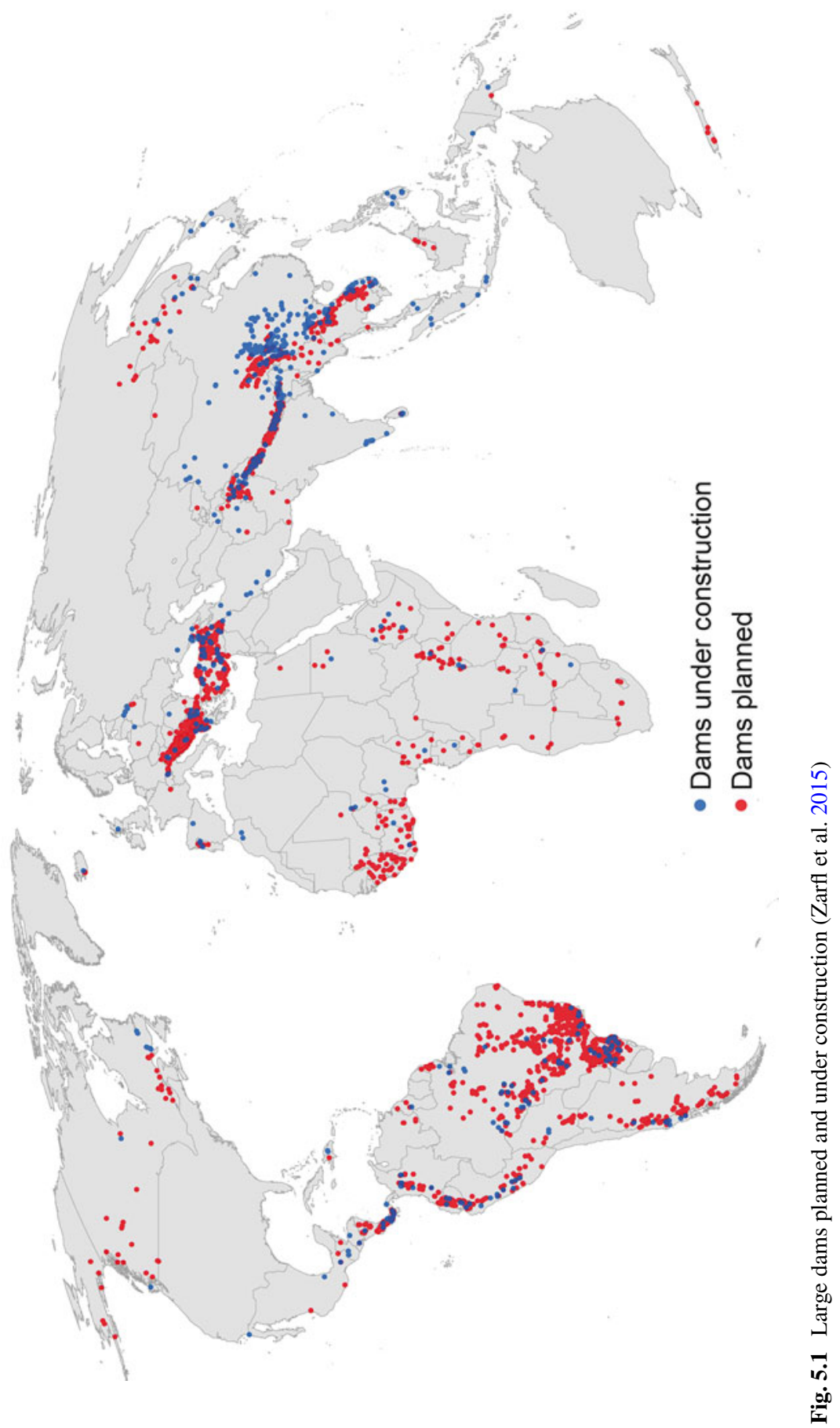


to 1.4 billion people who still remain disconnected from electricity supply. Large dams will primarily provide energy for industry and the mining sector, while the establishment of a extensive grid network would be required to serve rural human communities. Therefore, small, decentralised systems might probably be more effective to close the electricity gap.

Water management has historically emphasised services that depend on infrastructure such as navigation, irrigation, and hydropower (Auerbach et al. 2014). However, infrastructure projects create trade-offs and affect the services provided by natural ecosystems such as fishery yield, floodplain agriculture, cultural aspects, and the intrinsic values of biodiversity (ibid.). Indeed, one needs to be very careful in considering the trade-offs of maximising only a particular set of services. Today, navigation or hydropower production are considered as ecosystem services, although they impose major trade-offs with the service provided by a healthy ecosystem, e.g. a free-flowing river (Auerbach et al. 2014). Therefore, evaluating the benefits and trade-offs of large water infrastructure projects needs to consider both the ecosystem services provided by free-flowing rivers as well as the services provided by technical and engineered structures.

Mitigation of the impacts of large dams and other infrastructure projects may be very expensive. Because most future large dams will be constructed in developing countries and emerging economies, it will be particularly difficult to cover the associated costs. The question is not, however, if we should build new dams or not. The questions are where to build dams, how to construct them, and how to operate them. Therefore, there is an urgent need to further develop existing standards such as the Hydropower Sustainability Assessment Protocol (International Hydropower Association 2010), which must consider the economic, social, and ecological consequences of future dams. Furthermore, present dams are primarily evaluated individually, while ignoring the cumulative effects of multiple dams.

\subsection{Making Ecosystem Services and Distributional Concerns Visible and Incorporating Them into Decision Making}

\subsubsection{The Concept of Total Economic Value}

Although water resources are vital for the functioning of any economy, they continue to be depleted and degraded at an unsustainable rate (Birol et al. 2006, p. 106).

With a rising world population, the demand for water, food, and energy increases. The so-called "water-food-energy nexus" is a fundamental and increasing challenge for society (Russi et al. 2013). Water is a source of life for humans and nature. Without drinking water humans cannot survive. Without water any production of food or biomass becomes impossible. It is a resource that can be used for multiple purposes such as health and sanitation, agriculture and aquaculture, renewable energy generation and storage, among others. 
To some extent, the different options in water uses are mutually exclusive and constitute a potential for conflicting interests. For example, water consumed for drinking is no longer available for other uses or users. It is economically rational to minimise trade-offs and maximise net gains, particularly through the application of multifunctional management approaches. ${ }^{1}$ Management decisions on water resources therefore have to consider these trade-offs (Falkenmark and Rockström 2006). Assessments that provide reliable data can help to inform decisions on efficient resource use (Poff et al. 2003). In this respect, it is decisive to include all water-related services into consideration. To account for all associated costs and benefits of different uses, an overarching value framework is required.

Economics can provide such an overarching framework. ${ }^{2}$ The concept of total economic value (TEV) represents a general framework to assess all values water delivers to humans. It is an anthropocentric view ${ }^{3}$ where values go far beyond direct use values. Economic values do not consider just the (market) values of directly used goods and services (e.g. drinking water, water for irrigation), but also those subject to an indirect use, such as ground or surface water regulating services for agricultural production or flood control (e.g. high water tables, providing wetlands for a protection against flooding). In addition to these use-values, the TEV covers values assigned to a non-use of the resource such as bequest, altruistic, or existence values. Bequest values point to the fact that people have a benefit if certain water services are important for future generations (their children and grandchildren). Altruistic values are benefits people obtain from the fact that other people have water resources sufficiently at hand. And existence values point to the fact that people have a benefit just from the existence of water resources, e.g. certain species, irrespective of whether they see and enjoy this species. Between the use values and non-use values, there is the "option value" that points to the fact that keeping an option might be beneficial for humans (e.g. the option of future water benefits obtained from water tables where the benefits are not yet known). Figure 5.2 provides an overview of the TEV framework.

\footnotetext{
${ }^{1}$ Dams often serve a single goal. According to ICOLD Data (2014) over $70 \%$ of the world's large dams are single purpose dams and half of them are constructed for irrigation.

${ }^{2}$ We see such an economic approach, which is based on a comprehensive understanding of advantages and disadvantages of a MWEP, in line with the framework developed in Sect. 3.1 of this volume. The economic valuation approach, as we see it, can serve as a comprehensive method taking the assessment principles derived in Sect. 3.1 into account.

${ }^{3}$ As will be shown below, we are fully aware that there exist also holistic approaches of water values where intrinsic values and additional ethical issues are considered, too (Young 2005a, b). These approaches include the aspect that water is not primarily considered as a resource for humans ("water as a means"), but also as a living entity with a non-economic value ("water as an end"). Freshwaters are among the most diverse, complex and dynamic ecosystems globally, at the same time they are more threatened than many other systems (e.g., Living Planet Index 2014). Therefore, many argue that there is an urgent need to balance the needs for humans (anthropocentric view) and nature (non-anthropocentric view) (e.g. Pahl-Wostl et al. 2013).
} 


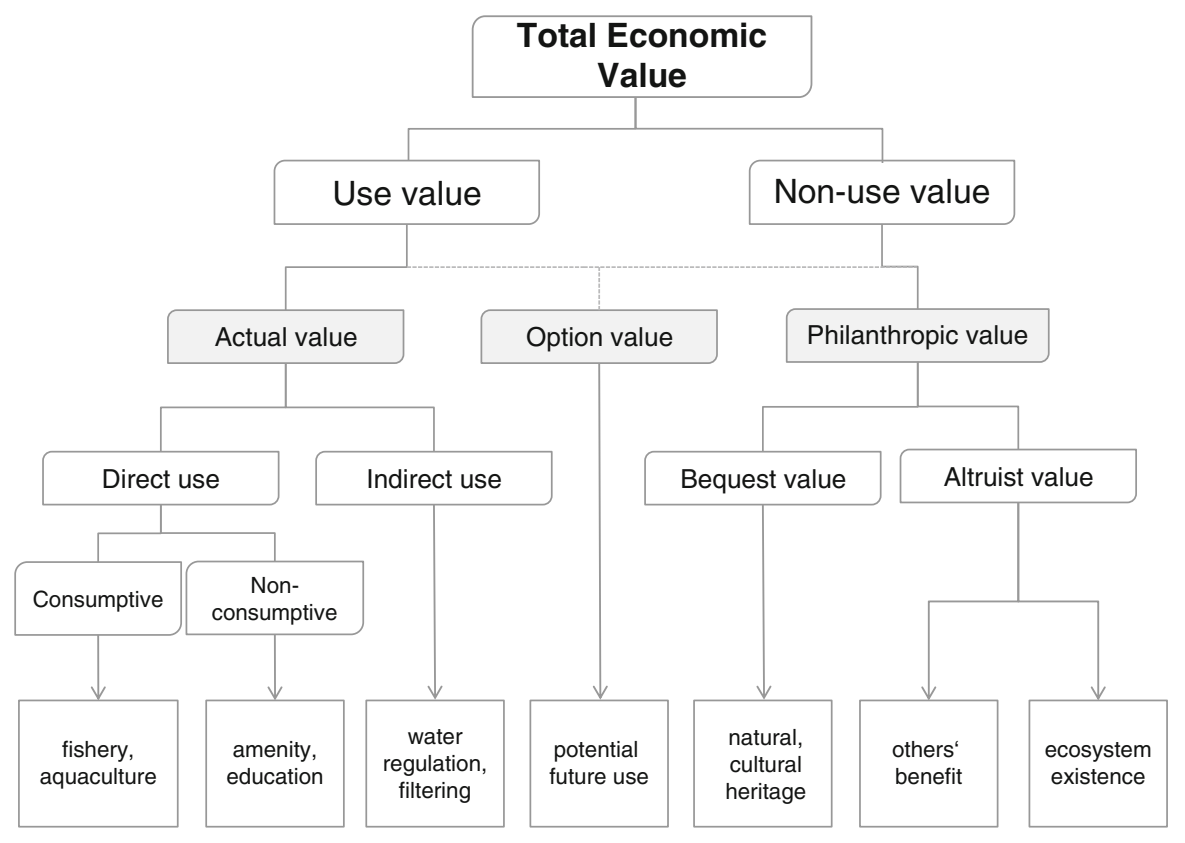

Fig. 5.2 Value types within the TEV approach (Adapted from TEEB 2010, p. 195)

Two remarks are worth mentioning here:

1. The economic approach of values of large water infrastructure projects is an anthropocentric one; benefits are derived from people's preferences ("water as a means"). This means that "intrinsic values" of water are not covered. If for example water infrastructure projects are rejected because people think that water has a value in itself ("water as an end"), this cannot be captured by economic valuation. Also values that a society as a whole might consider important (i.e. values that go beyond the aggregation of individuals' preferences) are not included. ${ }^{4}$

2. Nevertheless the economic valuation approach captures a rather broad set of values. The decisive point here is that all affected humans and all services of major infrastructure projects are to be included. Thus, ecological services (benefits) are integral part of this concept. This allows in particular to conceptually address ecological trade-offs, which are induced by major water engineering projects, and the identification of people who are negatively impacted by large projects through re-settlements or other forms of disadvantages (costs).

\footnotetext{
${ }^{4}$ Sometimes it is difficult to distinguish between "self-interested" economic preferences and "common-interested" societal values. The distinction by Vatn (2009) might be helpful here, who speaks of "I-preferences" (people value, act, and decide as self-interested entities) and "We-preferences" (where people value, act, and decide as members of society, setting aside their self-interest and focusing more on the joint production of common goods).
} 


\subsubsection{Ecological Trade-Offs}

Natural biogeochemical processes and diverse communities of aquatic biota regulate freshwater quantity and quality in ways that are not sufficiently acknowledged nor appreciated by the water resources management community (Arthington and Naiman 2010, p. 1).

In a majority of MWEPs, environmental impacts and consequences for ecosystem services and human well-being are underestimated (World Commission on Dams 2000; Russi et al. 2013). The Three Gorges Project (Gleick 2009; Fu et al. 2010) or the Aral Sea basin (Cai et al. 2003) are examples of large scale environmental impacts that have been underestimated at early planning stages. Ecological costs are difficult to estimate since they partly become apparent only in the longer run. Nevertheless, it has become obvious (especially in the Aral Sea basin case) that these ecological impacts have destroyed an entire landscape, with severe consequences not only for environmental but also for human health.

The conceptual framework of ecosystem services accounts for four categories of services that people derive from ecosystem functions (Millennium Ecosystem Assessment 2005a, b; Russi et al. 2013).

- Provisioning services are water for consumptive uses (drinking water, irrigation), nonconsumptive uses (hydropower, navigation), and food, medicine, and genetic resources.

- Regulating services are maintenance by water (filtration), climate (carbon sequestration), or natural hazard regulation (flood and erosion).

- Cultural services are nonmaterial benefits such as recreation, learning, cultural heritage, tourism, or existence values.

- Supporting services are those services required to maintain the overall functioning of ecosystems such as primary production and ecosystem resilience that often have long-term effects on people's benefits (Russi et al. 2013).

While in the past provisioning services have regularly been captured by economic analysis, it is the long-term impacts on ecosystems that have long been neglected in economic assessment methods for costs and benefits. Nevertheless, these ecosystem services are important for people's welfare. The Millennium Ecosystem Assessment (2005a) clearly showed how much people's well-being depends on functioning ecosystems and their services, and that many ecosystems are not managed sustainably. Management decisions that omit effects on the functioning of ecosystems and losses in their (provisioning, regulating, cultural, and supporting) services are therefore incomplete and likely have deteriorating consequences for ecosystem service provision and human well-being.

One illustrative example might be the greenhouse gas emissions from creating large reservoirs. While hydropower generally is considered a renewable source of energy, newly created reservoirs emit substantial amounts of greenhouse gases due to organic matter decomposition (World Commission on Dams 2000; Fearnside 2002; Mäkinen and Khan 2010). Emission rates are highly site specific and depend, for example, on reservoir age and latitude (Barros et al. 2011). Indeed, emissions from reservoirs may even outnumber the emissions by a com- 
parable fossil-fuel station by a factor of up to four (Giles 2006). Energy policies that do not take such emissions into account may cause external effects to the global climate and affected communities.

Another example is the loss of natural floodplains. In Germany, around $70 \%$ of originally natural floodplains have been disconnected from rivers or lost by built infrastructure (Brunotte et al. 2009). This has led to severe - also economic - damages. Especially in rural areas, the ecosystem services of nutrient retention and carbon sequestration in restored natural floodplains often exceed the value of built infrastructure (Scholz et al. 2012). MWEPs that do not take into account these ecosystem services and only look at costs of man-made flood protection vs. costs of ecological restoration are hardly efficient in cost-benefit-considerations.

These are only selected examples. Costs and benefits are always project-specific and site-dependent. But in general, it can be concluded that any comprehensive assessment has to account for all ecosystem services (including ecological impacts) and the costs of their deterioration or the benefits that they may provide for humans. Any policy that is based on an incomplete assessment of costs and benefits (because it focuses only on tangible costs and benefits or on costs and benefits that merely affect the business sector) is likely to be incomplete. If MEWP shall be sustainable in the long run (meaning that the decision for the MEWP is not considered as a fault after a few years), comprehensive economic valuation is not only required, but essential for choosing the right decisions.

\subsubsection{Social Conflicts}

Our language reflects $[\ldots]$ ancient roots: 'rivalry' comes from the Latin rivalis, or 'one using the same river as another.' Riparians - countries or provinces bordering the same river - are often rivals for the water they share (Wolf et al. 2005, p. 80).

Social conflicts are often closely related to the distribution of benefits and costs (Bernauer et al. 2012). In the real world, most MWEPs that generate benefits only to some groups in society and losses to others are subject to a potential conflict. These benefits and losses are very often associated with power relations. Ohlsson (2000) argues that the source of MWEPs conflict is not water scarcity itself but the required institutional change following large scale engineering to govern the scarce resource. The Human Development Report (UNDP 2006, p. 2) also states that the "scarcity at the heart of the global water crisis is rooted in power, poverty and inequality, not in physical availability".

Here, one important step to avoid or reduce conflicts is to explicitly address distributive impacts in decision support schemes. Who are the individuals or societal groups affected by the MWEPs? Are indigenous people or vulnerable groups particularly affected? What are alternatives? How can people be compensated? Thus it is decisive to include distributive aspects into (economic) analysis of major water 
infrastructure projects. Such distributive effects can be assessed quantitatively and qualitatively to build up a knowledge base for potential solutions (TEEB 2012, p. 31). In case distributional effects are not sufficiently taken into account potential conflicts may incur substantial economic (welfare) losses.

Involuntary or uncompensated re-settlements and losses of heritage sites may provide an example. Creation of large reservoirs for hydropower often requires that farmers and settlements are to be relocated. This entails not just the loss of nutrient rich high-yield marsh soils for farming, but often historically important settlement areas, cultural heritage sites, and aesthetic and recreational services. Some of these values may never be recovered - such as the loss of cultural heritage. Other values may be recovered such as the value of agricultural production. It is basically an ethical and often a political question of whether these values can be offset, compensated for or outweighed by benefits.

Another example may be provided by trans-boundary water conflicts caused by different goals and needs in different countries along the same river. Water is rival in its use - meaning that water used for a specific purpose is often not available for other uses. These trade-offs occur over space and time when hydropower is required upstream in winter, but downstream agricultural irrigation is required in summer like in the Syrdarya basin (see Chap. 7).

Economically speaking these "social costs" (impacts on ecosystem services, vulnerable groups or indigenous people that are not covered in market relations) have to be accounted for - otherwise an infrastructure investment decision like a dam might constitute a decision that turns out to be inefficient in terms of welfare. Whether this is practically feasible is not just a question of a proper assessment but also political will, power, and (democratic) institutions.

\subsubsection{Potential and Limits of Economic Analysis}

An informed decision on whether to build or not to build e.g. a large dam is not just a question of "yes" or "no" but also about different options to realise a certain goal, let it be flood control, food security, or electricity generation. Such a decision involves inevitable trade-offs. A well-designed analysis of different options and their associated costs and benefits can show which alternative actually yields the largest positive net benefit.

Figure 5.3 exemplifies hypothetical use scenarios for fresh water bodies. Optimising a single service or benefit dimension such as hydropower or ecosystem services does not necessarily yield an overall optimum. Finding balanced solutions that take into account multiple value dimensions may create the largest net benefits.

A comprehensive analysis that compares the advantages (benefits) and disadvantages (costs) of different scenarios for the use of water and wetland resources among multiple value dimensions can identify the best choice option. One policy goal could be secure water access and availability for a certain region. Another policy goal might be renewable energy production by hydropower. A third policy goal might be 


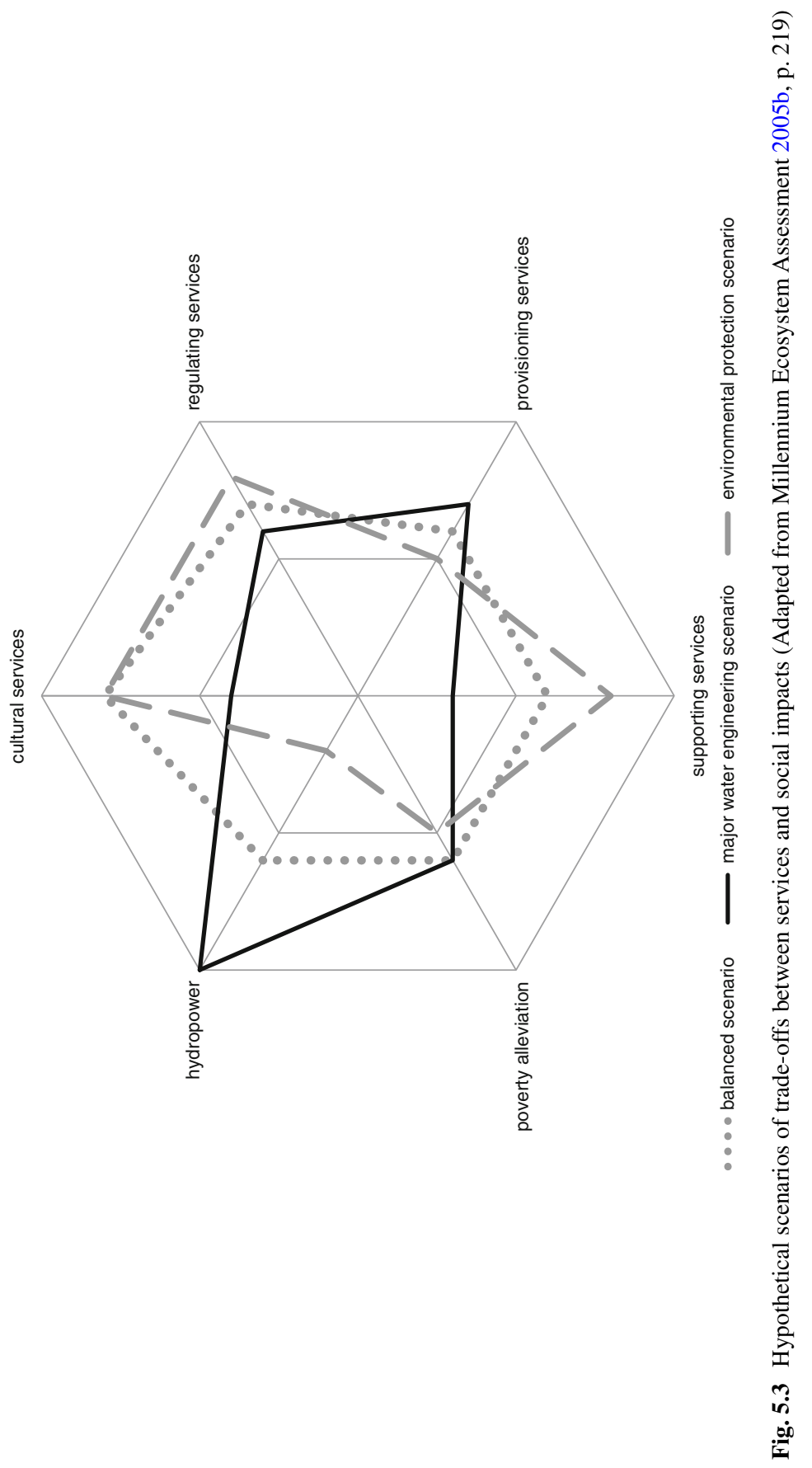


sustaining a healthy environment. The decisive point here is that all impacts should be considered - and not only a single one. We see this as a major fault in past decisions on dam building where in many cases the focus was merely on energy production.

The actual management options to realise a single or multiple of these goals can look quite different and can incur different costs and benefits. It could be naturebased or technical, decentralised or centralised, small- or large-scale. After an identification of potential approaches, different options could be compared by cost-benefit-analysis (Hansjürgens 2004), multi-criteria-analysis (Hansjürgens 2011), or other methods (TEEB 2010, 2012).

If properly designed an economic analysis can thus be an important source for decision-making and can ideally ensure that all relevant costs and benefits are taken into account.

\subsection{Concluding Remarks}

Major water engineering projects (MWEPs) can have both substantial benefits and costs. Which one prevails is not just a question of the project but also of the assessment. If substantial trade-offs such as irreversible losses in ecosystem services or social costs are neglected, it will be perceived as beneficial, while the extent of losses remains hidden. Hence, based on such an incomplete informational basis, no large-scale investment decisions should be made. By already taking the neglected values of water into account during the planning phase of MWEPs, the faults of the past could be avoided.

We have presented an economic framework, namely the Total Economic Value (TEV), to assess the often neglected costs and benefits; and there is a range of potential valuation methods that can be used to assess the related costs and benefits of various options (TEEB 2010).

However, a definition of what values, stakeholders, and effects are relevant can never be an exclusively scientific task. The realisation of projects fundamentally depends on political and societal actors and embedding institutional structures. It therefore also requires approaches and engagement beyond science - one could call them transdisciplinary. To comprehensively assess the outcomes of water-related investment decisions, our key recommendation is to integrate science, stakeholders, and political decision makers within an integrative, participatory, and process-based assessment approach - especially if large-scale outcomes are to be expected.

Open Access This chapter is distributed under the terms of the Creative Commons Attribution Noncommercial License, which permits any noncommercial use, distribution, and reproduction in any medium, provided the original author(s) and source are credited. 


\section{References}

Ansar A, Flyvbjerg B, Budzier A et al (2014) Should we build more large dams? The actual costs of hydropower megaproject development. Energy Policy 69:43-56

Arthington A, Naiman R (2010) Preserving the biodiversity and ecological services of rivers: new challenges and research opportunities. Freshw Biol 55(1):1-16

Auerbach DA, Deisenroth DB, McShane RR et al (2014) Beyond the concrete: accounting for ecosystem services from free-flowing rivers. Ecosystem Services 10:1-5

Barros N, Cole JJ, Tranvik LJ et al (2011) Carbon emission from hydroelectric reservoirs linked to reservoir age and latitude. Nat Geosci 4:593-596

Bernauer T, Böhmelt T, Koubi V (2012) Environmental changes and violent conflict. Environ Res Lett 7:015601

Birol E, Karousakis K, Koundouri P (2006) Using economic valuation techniques to inform water resources management: a survey and critical appraisal of available techniques and an application. Sci Total Environ 365:105-122

Biswas A, Tortajada C (2001) Development and large dams: a global perspective. Water Resour Dev 17:9-21

Brunotte E, Dister E, Günther-Diringer D et al (2009) Flussauen in Deutschland. Erfassung und Bewertung des Auenzustandes. Bundesamt für Naturschutz (BfN), Bonn - Bad Godesberg

Cai X, McKinney DC, Rosegrant MW (2003) Sustainability analysis for irrigation water management in the Aral Sea region. Agric Syst 76:1043-1066

Falkenmark M, Rockström J (2006) The new blue and green water paradigm: breaking new ground for water resources planning and management. J Water Resour Plan Manag 132(3):129-132

Fearnside P (2002) Avanca Brasil: environmental and social consequences of Brazil's planned infrastructure in Amazonia. Environ Manag 30:735-747

Fu B, Wu B, Lü Y et al (2010) Three Gorges project: efforts and challenges for the environment. Prog Phys Geogr 34:1-14

Giles J (2006) Methane quashes green credentials of hydropower. Nature 444:524-525

Gleick P (2009) Three Gorges dam project, Yangtze River, China. In: Gleick PH, Palaniappan M, Morikawa M et al (eds) The World's water 2008-2009. Island Press, Washington, DC, pp 139-150

Hansjürgens B (2004) Economic valuation through cost-benefit analysis - possibilities and limitations. Toxicology 205:241-252

Hansjürgens B (2011) Bewertung von Wasser in Landschaften - Konzepte, Ansätze und Empfehlungen. acatech - Deutsche Akademie der Technikwissenschaften, München

ICOLD (2014) Register of dams. http://www.icold-cigb.org/GB/World_register/world_register. asp. Accessed 14 Jan 2015

International Hydropower Association (2010) Hydropower sustainability assessment protocol. International Hydropower Association, London

Lehner B, Liermann CR, Revenga C et al (2011) High-resolution mapping of the world's reservoirs and dams for sustainable river-flow management. Front Ecol Environ 9:494-502

Mäkinen K, Khan S (2010) Policy considerations for greenhouse gas emissions from freshwater reservoirs. Water Alternat 3:91-105

Millennium Ecosystem Assessment (2005a) Ecosystems and human well-being: synthesis. Island Press, Washington, DC

Millennium Ecosystem Assessment (2005b) Ecosystems and human well-being: policy responses. Island Press, Washington, DC

Moore D, Dore J, Gyawali D (2010) The world commission on dams + 10: revisiting the large dam controversy. Water Alternat 3:3-13

Ohlsson L (2000) Water conflicts and social resource scarcity. Phys Chem Earth (B) 25:213-220

Pahl-Wostl C, Arthington A, Bogardi J et al (2013) Environmental flows and water governance: managing sustainable water uses. Curr Opin Environ Sustain 5:341-351

Poff N, Hart D (2002) How dams vary and why it matters for the emerging science of dam removal. Bioscience 52:659-668 
Poff N, Allan J, Palmer M (2003) River flows and water wars: emerging science for environmental decision making. Front Ecol Environ 1:289-306

Russi D, ten Brink P, Farmer A et al (2013) The economics of ecosystems and biodiversity for water and wetlands. Gland, London/Brussels

Scholz M, Mehl D, Schulz-Zunkel C et al (2012) Ökosystemfunktionen von Flussauen - Analyse und Bewertung von Hochwasserretention, Nährstoffrückhalt, Kohlenstoffvorrat, Treibhausgasemissionen und Habitatfunktion. Bad Godesberg, Bonn

Shah Z, Kumar M (2008) In the midst of the large dam controversy: objectives, criteria for assessing large water storages in the developing world. Water Resour Manag 22:1799-1824

TEEB (2010) The economics of ecosystems and biodiversity: the ecological and economic foundations. Earthscan, London/Washington

TEEB (2012) The economics of ecosystems and biodiversity for local and regional policy makers. Earthscan, London/Washington

UNDP (2006) Human development report 2006 beyond scarcity: power, poverty and the global water crisis. UNDP Human Development Reports

Varma CVJ (2001) ICOLD's final position on the WCD report. http://www.unep.org/dams/documents/default.asp?documentid=453. Accessed 14 Jan 2015

Vatn A (2009) An institutional analysis of methods for environmental appraisal. Ecol Econ 68:2207-2215

Wolf AT, Kramer A, Carius A et al (2005) Managing water conflict and cooperation. In: Assadourian E, Brown L, Carius A et al (eds) The state of the world. Redefining global security. Worldwatch Institute, Washington DC, pp 80-95

World Commission on Dams (2000) Dams and development a new framework for decisionmaking. Earthscan, London

Young R (2005a) Determining the economic value of water: concepts and methods. Resources for the Future, Washington, DC

Young R (2005b) Water as an economic good. In: Brouwer R, Pearce D (eds) Cost-benefit analysis and water resource management. Edward Elgar, Cheltenham, pp 13-45

Zarfl C, Lumsdon AE, Berlekamp J et al (2015) A global boom in hydropower dam construction. Aquat Sci 77:161-170 